\title{
Diffusion-Weighted-Imaging Negative Stroke Syndromes
}

\section{Difüzyon A ̆̆ırlıklı Görüntüleme Negatif İnme Sendromları}

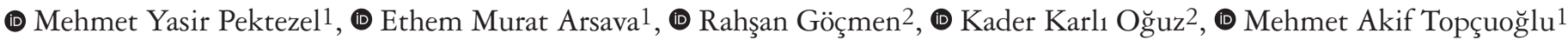 \\ ${ }^{1}$ Hacettepe University Faculty of Medicine, Department of Neurology, Neurology Intensive Care Unit, Ankara, Turkey \\ 2Hacettepe University Faculty of Medicine, Department of Radiology, Ankara, Turkey
}

\begin{abstract}
Objective: Normal diffusion-weighted imaging (DWI) during the acute symptomatic phase of an ischemic stroke is a rare, but a well-known phenomenon. The exact rate and the clinical correlates of this phenomenon are not satisfactorily elucidated.

Materials and Methods: Consecutive patients who were hospitalized with the diagnosis of acute ischemic stroke in the last 10 years and who had DWI (with a bmax of $1000 \mathrm{~s} / \mathrm{mm}^{2}$ ) in the first 12 hours were included. A systematic review of published DWI-negative stroke cases and case series was performed. Alternate diagnoses including transient ischemic attack or stroke mimics such as seizure, migraine, functional disorders, and post-stroke recrudescence were excluded.

Results: The diagnosis of DWI-negative stroke syndrome was made in 20 (1.3\%) of 1.506 patients hospitalized in Hacettepe Hospitals. A literature search disclosed another 535 (6.6\%) DWI-negative strokes out of 8.101 cases. A total of 115, identified in case reports and cohort $(\mathrm{n}=19)$ articles, were combined with our cases to delineate further characteristics of DWI-negative clinical stroke syndromes. DWI-negative syndromes $(\mathrm{n}=135)$ were "brainstem mini-strokes" ( $31.1 \%)$, "cortical small embolic infarcts" (5.2\%), "pure penumbral stroke" (normal DWI with magnetic resonance perfusion deficit) (34.8\%); "aborted stroke" (early and fully recanalized stroke, only diagnosable in patients with documented acute vessel occlusion) (5.2\%); and "miscellaneous" (23.7\%). Corresponding clinical stroke syndromes include partial hemispheric deficits $(36.1 \%)$, focal cortical syndromes (4.3\%), caudal brainstem syndromes $(9.3 \%)$, acute isolated vertigo $(9.3 \%)$, vertigo-plus syndromes (10.1\%), ocular syndromes (7.4\%), movement disorders (1.9\%), typical lacunar syndromes (11.1\%), and atypical lacunar syndromes such as ataxia \pm dysatrhria $(9.3 \%)$.
\end{abstract}

Conclusion: In clinical practice of acute ischemic stroke, early DWI imaging can be negative in various clinical syndromes. Imaging repetition is necessary for the diagnosis and management plan of these patients.

Keywords: Diffusion-weighted imaging, neurologic examination, neurologist, medical history taking, stroke, imitator

Öz

Amaç: İskemik inmenin akut fazında normal diffüzyon ağırlıklı görüntüleme (DAG) izlenmesi nadir, ama iyi bilinen bir fenomendir. Bu durumun kesin oranı ve karşılık gelen klinik korelasyonları yeterli derecede incelenmemiştir.

Gereç ve Yöntem: Son 10 yıl içerisinde akut iskemik inme tanısı ile hastaneye yatırılan ve ilk 12 saat içerisinde DAG çekilen peşi sıra hastalar çalışmaya alınd. Ek olarak, literatürde yayınlanan DAG negatif inme olgu sunumu ve serileri sistematik olarak derlendi. Geçici iskemik atak ve epileptik nöbet, migren, fonksiyonel bozukluklar, inme rekrüdesansı gibi inme taklitçileri dışlandı.

Bulgular: Hacettepe Hastaneleri'nde yatan 1,506 hastanın 20'sinde (\%1,3) DAG negatif inme sendromu tanısı kondu. Literatür taramasında 8,101 olgudan 535 $(\% 6,6)$ DAG negatif inme olgusu daha saptand. Olgu sunumları ve kohort makalelerinde tanımlanan toplam 115 olgu DAG negatif klinik inme sendromlarının özelliklerini tanımlamak için bizim olgularımızla birleştirildi. DAG negatif sendromlar ( $\mathrm{n}=135)$ "beyin sapı mini-inmeler" (\%31,1), "kortikal küçük embolik enfarktlar" $(\% 5,2)$, "saf penumbral inme" (manyetik rezonans perfüzyon defekti olduğu halde normal DAG; \%34,8), "durdurulmuş "(aborted)" "inme" (erken/ tamamen rekanalize inme, sadece akut damar tıkanıklı̆̆ının tıkanıp açıldı̆̆ı gösterilen olgularda teşhis edilebilir; (\%5,2) ve "çeşitli” (\%23,7). Karşılık gelen klinik inme sendromlar1 "kısmi hemisferik defisitler" (\%36,1), "fokal kortikal sendromlar" $(\% 4,3)$, "kaudal beyin sap1 sendromları" (\%9,3), "akut izole vertigo" $(\% 9,3)$, "vertigo-plus sendromlar" $(\% 10,1)$, oküler sendromlar $(\% 7,4)$, hareket bozukluklar1 $(\% 1,9)$ ile tipik laküner sendromlar $(\% 11,1)$ ve ataksi \pm dizatri gibi atipik laküner sendromlar $(\% 9,3)$ şeklindedir.

Sonuç: Akut iskemik inme klinik pratiğinde "DAG negatif inme sendromu" nadir değildir. Ancak, çok sayıda klinik tablo ve nöroanatomik lokalizasyonla birlikte olabildiği için spesifik olmaktan uzaktır. Klinik bulgular temelinde kontrol görüntüleme alınması ve difüzyon negatifliğinin mekanizmasının aydınlatılması makuldur.

Anahtar Kelimeler: Diffüzyon ă̆ırlıklı görüntüleme, nörolojik muayene, nörolog, anamnez, inme, taklitçi

Address for Correspondence/Yazışma Adresi: Mehmet Akif Topçuoğlu MD, Hacettepe University Faculty of Medicine, Department of Neurology, Neurology Intensive Care Unit, Ankara, Turkey

Phone: +903123051806 E-mail: mat@hacettepe.edu.tr ORCID: orcid.org/0000-0002-7267-1431

Received/Geliş Tarihi: 21.07.2020 Accepted/Kabul Tarihi: 19.01.2021

${ }^{\circledR}$ Copyright 2021 by Turkish Neurological Society

Turkish Journal of Neurology published by Galenos Publishing House. 


\section{Introduction}

Diffusion-weighted imaging (DWI) is a critical neuroimaging modality in the management of acute ischemic stroke. DWI has been reported to have a perfect (in the range of 95\%) sensitivity and almost $100 \%$ specificity (1). Despite this high accuracy, the reported false negativity rate is not negligible. Failure to diagnose acute stroke due to DWI-negativity may pose a serious risk of recurrence due to delayed/missed treatment plan (2,3). Herein, we aimed to delineate the frequency and demographic, clinical and neuroimaging features of DWI-negative acute ischemic stroke.

\section{Materials and Methods}

\section{Patients}

\section{First Part}

In the first part of the study, the last ten years of the Hacettepe University Stroke Unit database was retrospectively searched for patients admitted to the emergency department with signs and symptoms suggestive of acute ischemic stroke. Patients with transient ischemic attack (TIA), and those with subsequent alternate diagnoses such as seizure, migraine attack, functional disorder or post-stroke recrudescence were excluded. The analyses were then restricted to the remaining patients who were finally diagnosed as having an ischemic stroke in whom an initial DWI study was performed within 12 hours after symptom onset. Patients with no evidence of an acute ischemic lesion in the initial study despite the persistence of signs and symptoms beyond 24 hours, and having a DWI lesion compatible with neurologic signs at a follow-up study comprised the "DWI-negative ischemic stroke" group. "t1 time" was defined as the interval between the onset of symptoms to the first DWI study. "t2 time" was defined as the duration between symptom onset and the second DWI. Sex, age, stroke risk factors, National Institute of Health Stroke Scale (NIHSS), clinical presentation, DWI features in the second neuroimaging study and $\mathrm{t} 1 / \mathrm{t} 2$ durations were recorded.

Approval was obtained from Hacettepe University NonInterventional Clinical Research Ethics Committee for this study (decision number: 2020/16-25, date: 06/10/2020).

\section{Second Part}

In the second part of the study, we searched PubMed ${ }^{\circledR}$ with the keywords of "diffusion-weighted imaging," "negative," and "stroke," which yielded a total of 337 abstracts. From those, 60 abstracts were found to be relevant to our study in the initial screening. At the second stage, where the full-texts of these abstracts were evaluated, seven articles were not considered relevant to our research, three were not in the English language, and one article was a meta-analysis. Thus, the remaining 49 articles were evaluated for further analyses (Supplementary Figure 1).

To identify the exact rate of DWI-negative stroke, we extracted 19 of these articles where both the number of DWI-negative strokes and the total number of patients with stroke in the cohort were given. We also investigated the articles from this perspective because we aimed to describe the demographic and clinical features of patients who were DWI-negative. In 30 articles (21 of which were case reports or case series), the patients were described with their demographic, clinical, and magnetic resonance imaging (MRI) characteristics. From these articles, information about sex, age, stroke risk factors (described in most of the articles), NIHSS, clinical presentations, lesion location on second DWI-MRI, and t1/t2 durations were extracted. Although either t1 or t2 times have not been stated in some studies, all patients included in the current study underwent a second (confirmatory) MRI. Finally, this information was combined with the data of our center.

Pubmed was searched by keywords of 'diffusion weighted imaging, negative, stroke'

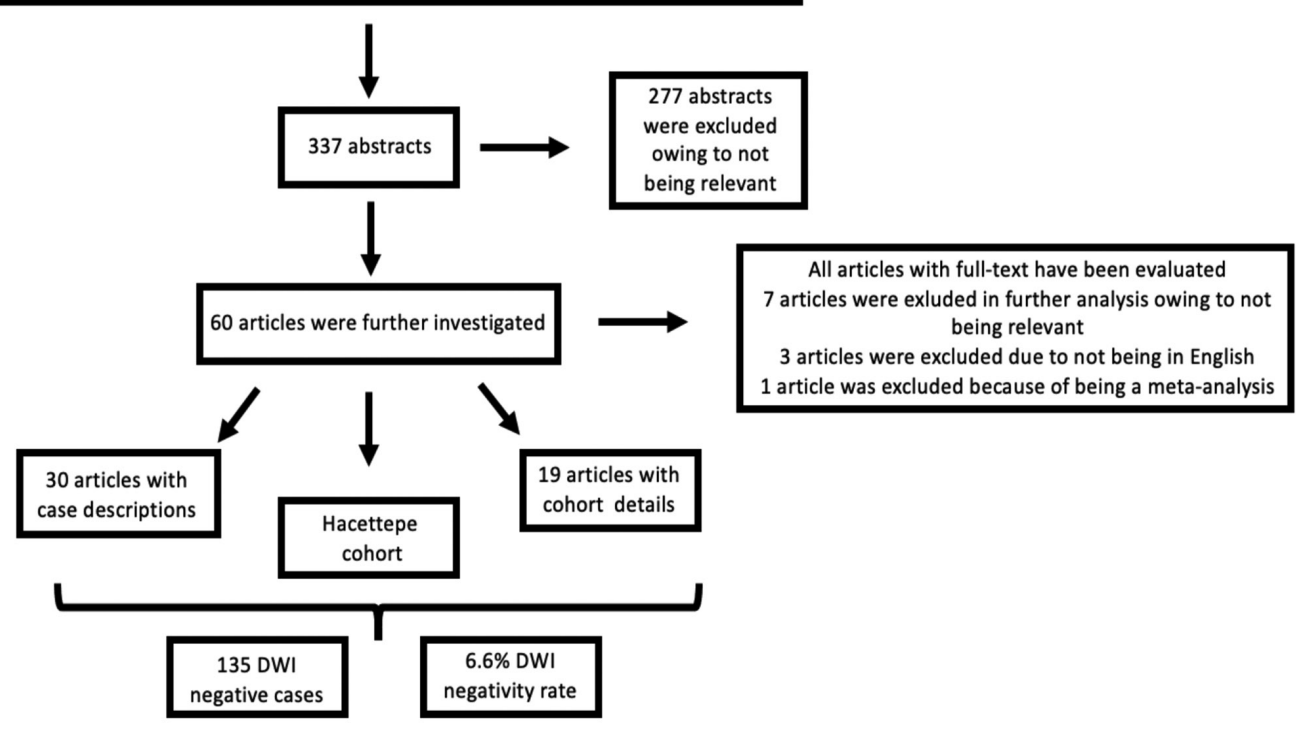

Supplementary Figure 1. The flowchart of the study

DWI: Diffusion-weighted imaging 


\section{Statistical Analysis}

All values are represented as mean \pm standard deviation, 95\% confidence intervals (95\%), percentages, medians with inter-quartile ranges as appropriate. The SPSS 23 IBM $^{\circledR}$ software provided by Hacettepe University Medical Faculty was used for calculations.

\section{Results}

\section{First Part}

A total of 1.506 patients with ischemic stroke were evaluated in Hacettepe University during the study period, of which 20 (1.3\%) were diagnosed as DWI-negative (on imaging obtained with a $\mathrm{b}_{\text {max }}$ of $1000 \mathrm{~s} / \mathrm{mm}^{2}$, which is the routine application in our institute) ischemic stroke. Ten $(50 \%)$ female. The mean age was $65 \pm 16$ years. The median NIHSS was $4(0-12)$ on admission. There was a history of chronic hypertension in $80 \%$ of these patients, the prevalence of dyslipidemia was $40 \%$, diabetes mellitus was $35 \%$, atrial fibrillation was $25 \%$, and prior stroke was $15 \%$. The median t 1 time was 5 (range, 3-9) hours, whereas the median $\mathrm{t} 2$ time was found as 34 (range, 24-73) hours.

\section{Second Part}

The combination of our series with the other 19 compatible cohorts from relevant literature yielded a DWI negativity rate of $6.6 \%$ in patients with ischemic stroke (535 DWI-negativestrokes among a total of 8.101 ischemic stroke patients). We were able to identify individual patient characteristics of 115 patients reported in the literature and combined them with our data. Among these 135 patients, $54(40 \%)$ were female. The mean age was $66 \pm 15$ years and the median NIHSS was found as 4 (range, 0-10) on admission. Additional disease information, which could not be obtained in all patients, is summarized in Table 1. Sixteen $(84 \%)$ out of 19 cohorts and most of the other reports included used a DWI sequence obtained with a $b_{\max }$ of $1000 \mathrm{~s} / \mathrm{mm}^{2}$. In the remaining cohorts, no information related to the issue was provided. The median $\mathrm{t} 1$ time, obtained in just $96(71 \%)$ patients, was 5 (range, 3-17) hours, whereas the median t 2 time obtained in $89(66 \%)$ patients was 29 (range, 20-84) hours.

DWI negative syndromes $(\mathrm{n}=135)$ were classified as "brainstem mini-strokes" (31.1\%, Figure 1); "pure penumbral stroke," which defines a DWI-negative imaging finding in the setting of certain perfusion deficit (34.8\%, Figure 2); "cortical small infarcts" (5.2\%, Figure 3); "aborted stroke," which defines early complete recanalization of initially documented acute cerebral artery occlusion (5.2\%, Figure 4); and "miscellaneous" (23.7\%). The miscellaneous group consisted of 10 patients who presented solely with cerebellar infarcts, five with centrum semiovale - capsular infarcts, and 17 with DWI lesions scattered through a variety of subcortical white matter. Detailed information on each classified condition can be found in Table 1 .

The corresponding clinical stroke syndromes were determined in $80 \%(n=108)$ of patients with DWI-negative stroke. The majority ( $n=39,36.1 \%$ ) of patients with DWI-negative stroke had hemispheric neurologic deficits such as anopia, dysphasia or hemiparesis (plegia). Further, six (4.3\%) had "focal cortical syndromes", which involved isolated hand/crural paresis in three, elements of Gerstmann's syndrome in two, and abulia in one patient. "Acute isolated vertigo" was diagnosed in 10 patients $(9.2 \%$, Figure 5$)$, all of whom had an acute small cerebellar infarct. "Vertigo-plus," described as vertigo with ataxia, nystagmus or dysmetria, was seen in $11(10.1 \%)$ patients. "Caudal brainstem syndromes," which included solely lateral medullar syndrome, were diagnosed in $9.3 \%(\mathrm{n}=10)$. A variety of "ocular syndromes" consisting of internuclear ophthalmoplegia in five, up-gaze palsy, diplopia with tinnitus, nystagmus with skew deviation in one each was diagnosed in eight $(7.4 \%)$ patients. "Movement disorders" presenting as hemiballismus was seen in two (1.9\%) patients. The remaining $22(20.3 \%)$ lesions were classified as "others," in which 12 patients had classic lacunar syndromes including six with ataxic hemiparesis, four with pure motor hemiparesis, and two with pure sensorial stroke. The remaining 10 patients presented with ataxia and/or dysarthria secondary to involvement of various posterior system arterial territories.

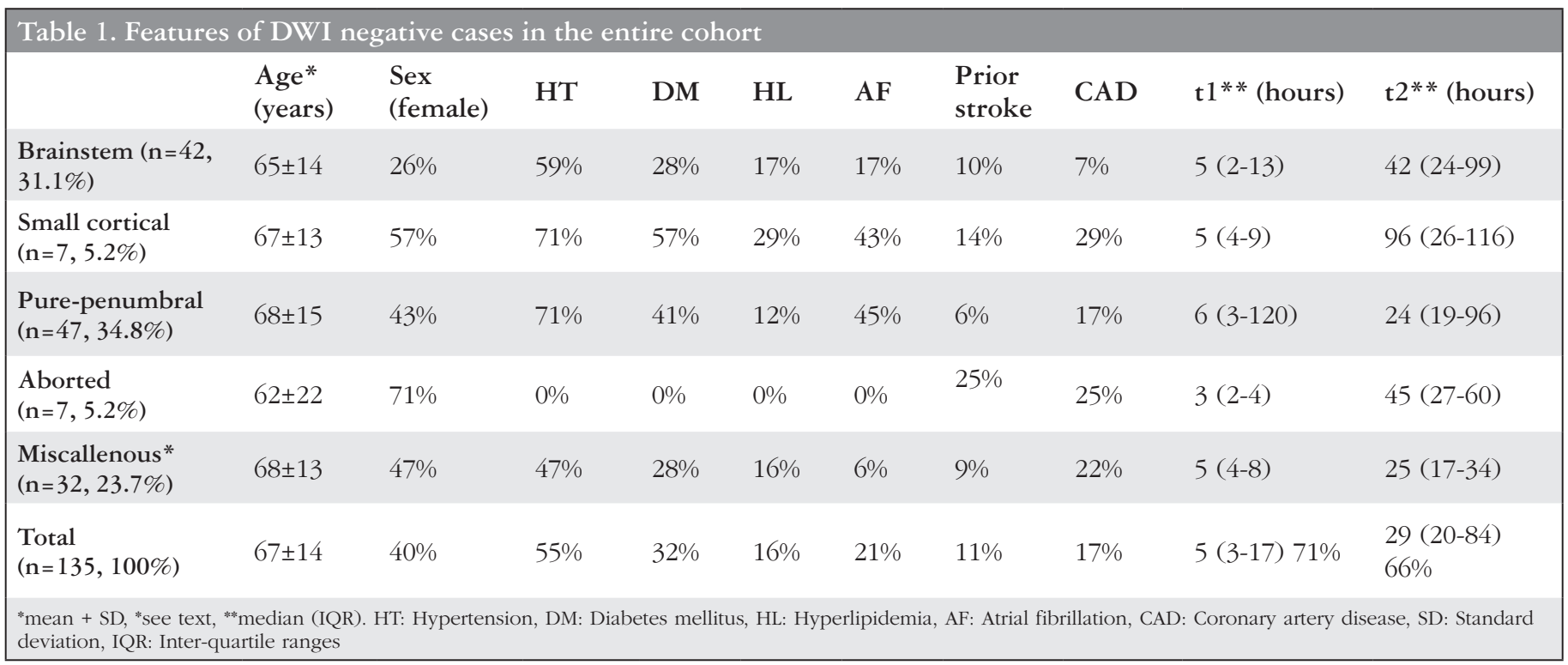




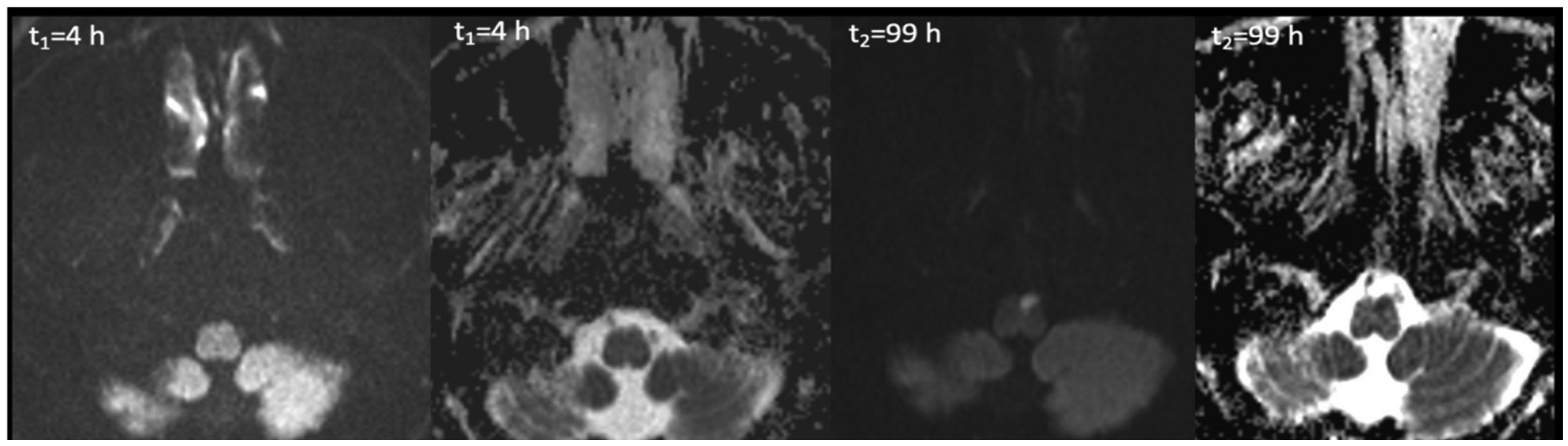

Figure 1. Brainstem mini-stroke: A 61-year-old man with hypertension and dyslipidemia was admitted with acute onset right-sided hemihypoesthesia, dysphagia and mild ataxia (admission NIHSS: 12; $4^{\text {th }}$-hour NIHSS: 10). While the lesion is not detected in the DWI and apparent diffusion coefficient (ADC) mapping performed at the fourth hour following the onset of the symptom, a DWI bright-ADC dark acute medullary infarction in the left medullary pyramid is clearly discerned in the control imaging taken at the ninety-ninth hour

NIHSS: National Institute of Health Stroke Scale, DWI: Diffusion-weighted imaging

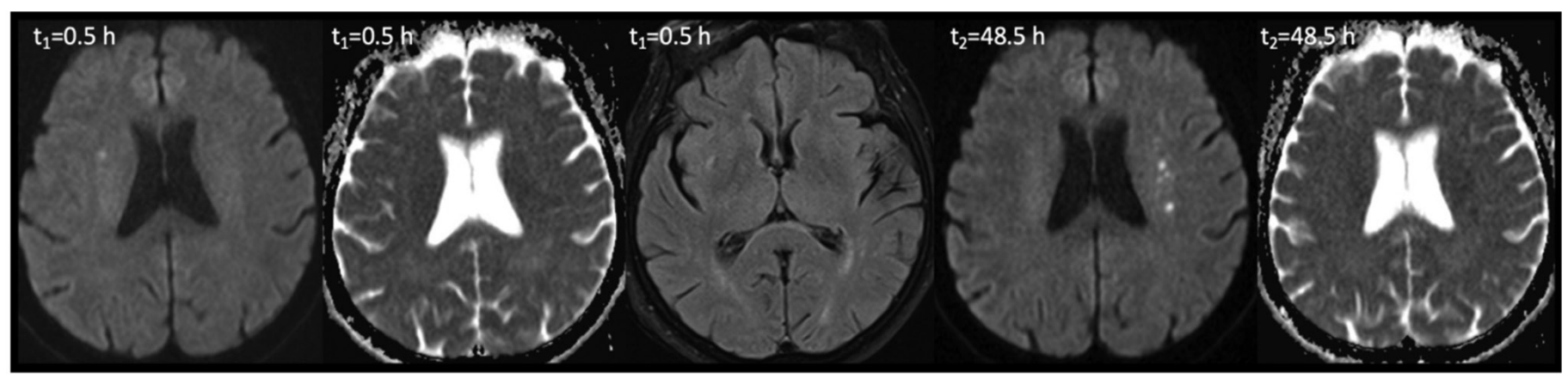

Figure 2. Pure penumbral stroke. A 76-year-old woman with known prior history of hypertension and coronary artery disease was consulted while she was being followed at the cardiovascular and chest surgery department after a coronary artery by-pass graft surgery. Transcortical sensorial aphasia and a left-sided central facial paresis were found on examination (admission NIHSS: 7; 24 ${ }^{\text {th }}$-hour NIHSS: 6). Diffusion restriction is not seen in DWI, which is completed a half-hour after the onset of the symptom. However, distal left MCA segment occlusion is detected on CT angiography. The vessel signs in FLAIR sequences are indirect markers of perfusion deficit are visible. In the second imaging taken 48 hours after the first one, the culprit lesion can be clearly detected as DWI bright and ADC dark ischemic lesion. There was no change in the patient's neurologic deficit during the interval

NIHSS: National Institute of Health Stroke Scale, DWI: Diffusion-weighted imaging, CT: Computed tomography, MCA: Middle cerebral artery, ADC: Apparent diffusion coefficient, FLAIR: Fluid-attenuated inversion recovery

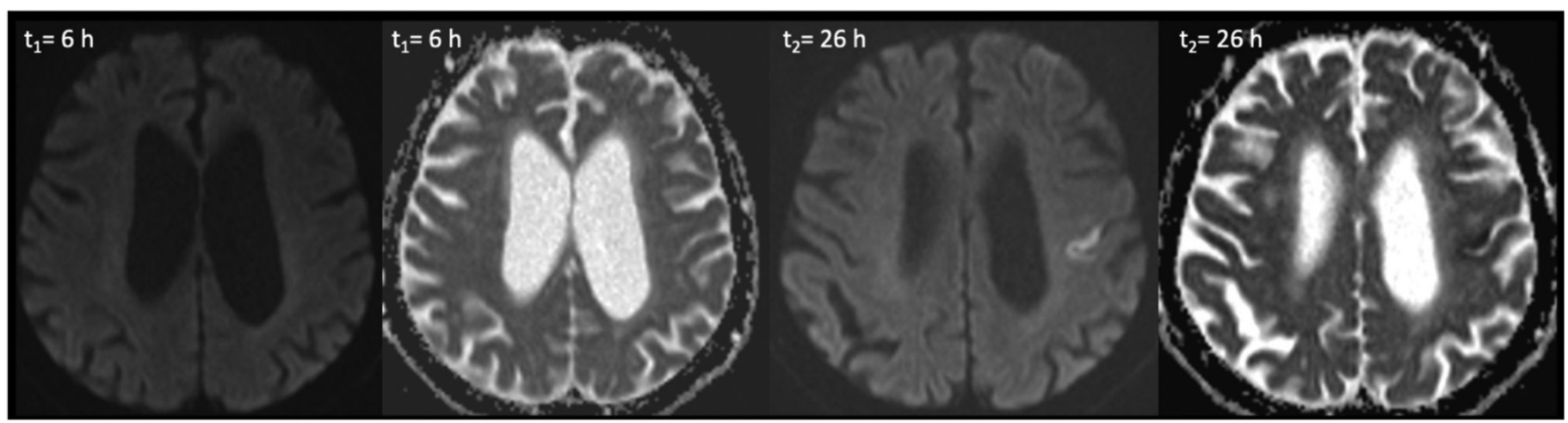

Figure 3. Isolated cortical syndrome: A 81 year-old-female with hypertension and atrial fibrillation was admitted with acute onset central facial paresis and dysarthria. (Admission NIHSS: 4; $24^{\text {th }}$ hour NIHSS: 4) While DWI performed at the sixth hour after the onset of the symptom did not document the lesion, DWI performed twenty hours later showed a small-sized cortical infarction in the posterior frontal lobe. The lesion involves the facial area of the homongulus in accordance with the clinic deficit

NIHSS: National Institute of Health Stroke Scale, DWI: Diffusion-weighted imaging 


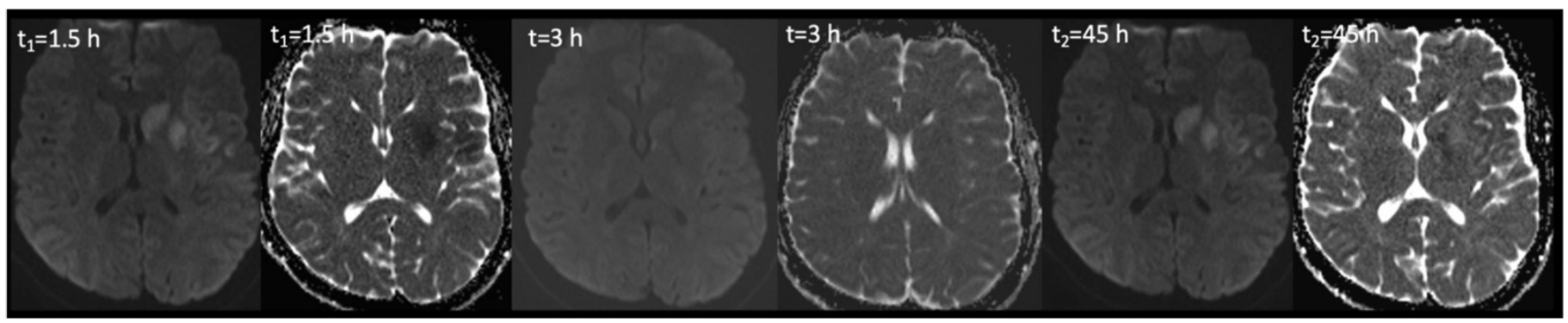

Figure 4. Aborted stroke: A previously healthy 32-year-old woman was admitted with acute onset right-sided hemiplegia and aphasia (admission NIHSS: 10; $24^{\text {th }}$-hour NIHSS: 3). Left-sided basal ganglia and insular infarction were observed in the DWI performed at the ninety minute after the onset of the event, lesions disappeared at the third-hour DWI, and the lesion reappeared at the end of the second day

NIHSS: National Institute of Health Stroke Scale, DWI: Diffusion-weighted imaging

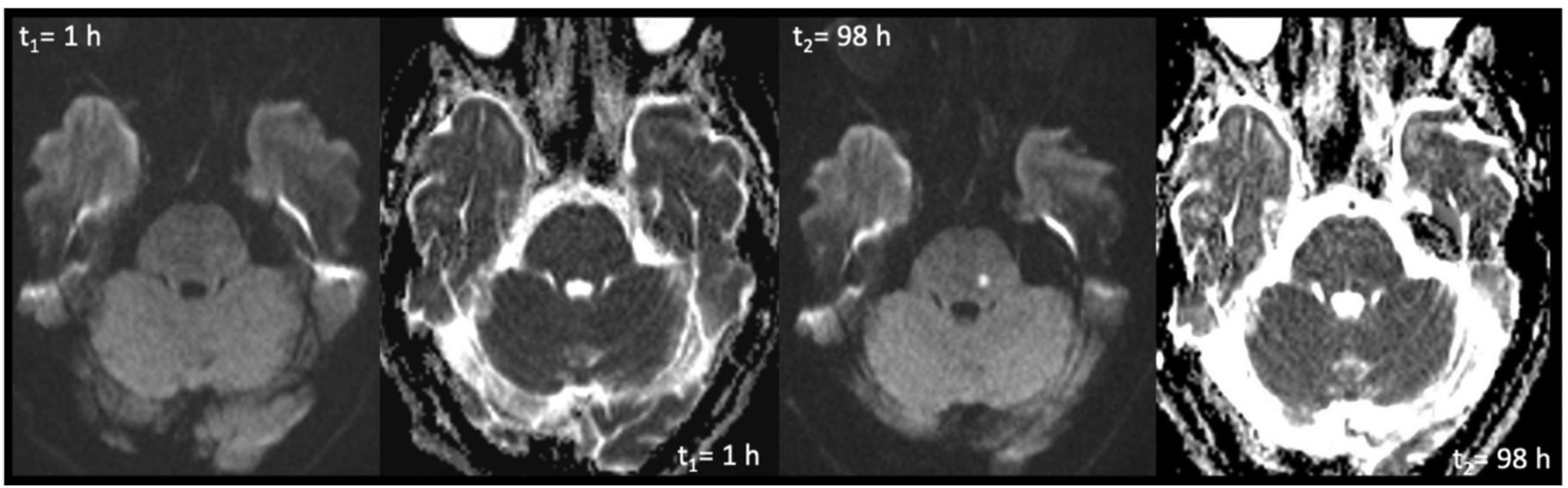

Figure 5. Vertigo: A 73-year-old woman with hypertension was admitted with acute onset vertigo and mild ataxia. (admission NIHSS: 4; $24^{\text {th }}$-hour NIHSS: 4). The left mid pons small infarction, which cannot be visible in DWI obtained at the end of the first hour of the symptom occurrence, is clearly observable at the ninety-eighth hour DWI

NIHSS: National Institute of Health Stroke Scale, DWI: Diffusion-weighted imaging

\section{Discussion}

DWI negativity is a problematic issue while managing ischemic stroke in the acute setting. Hitherto, to the best of our knowledge, no study has investigated DWI-negative stroke prevalence along with the individual features of patients by their demographic, clinical, and neuroimaging characteristics. The frequency of DWI-negative stroke is highly variable in the literature, ranging from $2.2 \%$ to $32.9 \%(2,3)$. In our study, when our single-center observations were combined with prior reports in the literature, DWI-negative stroke frequency was found as $6.6 \%$ of patients among patients with ischemic stroke. That is compatible with a previous meta-analysis (4) in which this rate was stated as $6.8 \%$. However, the $1 \%$ rate in our cohort is obviously below this level. This low rate may originate from various reasons including, but not limited to, different hospital logistics such as the distance of MR units to the emergency room, MR techniques used such as b-values and population characteristics such as stroke clinicimaging phenotype.

It is a matter of debate why some acute ischemic stroke lesions remain unnoticeable in DWI. Recently, it was shown that nearly $11 \%$ of patients with transient cerebrovascular dysfunction might depict an infarction on follow-up scans obtained beyond 24 hours, which evoked the importance of the timing of DWI to detect an acute ischemic lesion (5). It was stated that the sensitivity of $1.5 \mathrm{~T}$ DWI-MRI was $99.1 \%$ within the first 6 hours (1). However, the median imaging time was 10 hours in our study, which was much later than the period in this report. This gives the impression that the sensitivity of hyperacute DWI may not be as perfect as it is stated and perhaps needs to be revisited. On the other hand, the increasing signal intensity on DWI over the ensuing hours and days (reaching a maximum of 40 to 72 hours after the insult) increases the signal-to-noise ratio of DWI and thereby improves the detectability of lesions (6). This is in line with our results because the average $t 2$ time was 70 hours.

In addition to the timing of DWI, another important variable in terms of the sensitivity is the technical aspects of the imaging. It is shown that acute ischemic stroke lesions could be more easily detected by $3 \mathrm{~T}$ MRI DWI sequences in comparison to $1.5 \mathrm{~T}$ MRI, especially when lesions are small and localized in the brainstem (7). However, there is not a comparison regarding the use of magnetic power of MRI in patients with DWI-negative stroke. In addition to the magnet power of MRI, the slice thickness is also crucial, especially in infratentorial ischemic strokes. As a reflection of partial volume averaging, the sensitivity to detect an infratentorial infarction was found as $81.1 \%$ in $5 \mathrm{~mm}$-thick studies, improving 
to $94.6 \%$ in $3-\mathrm{mm}$ thick studies; the corresponding specificity was found as $100 \%$ and $97.7 \%$, respectively (8). On the other hand, the false-negative rate of DWI for an infratentorial infarct was found as $5.6 \%$ for 5 -mm thick sequences and $1.6 \%$ for 3 -mm thick sequences (8). The initially negative ischemic stroke lesions were usually small (average $4.8 \mathrm{~mm}$ in diameter) and tended to settle in the brainstem in the same study (8). An alternative opinion to explain the DWI negativity in the brainstem, apart from timing and technical features, is the diminution of the intra-vascular space, producing intracellular dehydration and delayed edema formation (9). Other opinions include the insufficient signal-to-noise ratio and magnetic susceptibility artifacts at the brainstem (10). The region-specific response to ischemia may be another mechanism because some brain regions are known to be more susceptible to ischemia than others (11). DWI can be falsely negative in strokes exclusively limited to the intensely axon-dense regions such as the posterior limb of the capsula interna.

In a recent study, $27 \%$ of patients with an acute transient vestibular syndrome were found to have a stroke in which nearly half had a cerebellar infarction on DWI and the rest had cerebellar hypoperfusion on perfusion-weighted imaging (12). In certain circumstances, cerebral blood flow reductions cause hypoperfusion, which is enough to produce symptoms but not severe enough to produce a diffusion positivity, thereby, hypoperfusion without restricted diffusion may be seen $(13,14)$. In a recent study, $44 \%$ of patients with ischemic stroke who had a perfusion deficit on the initial MRI scan showed at least a new DWI lesion in the following week $(15,16)$. Accordingly, MR imaging and regionspecific features are responsible for DWI negativity and perfusion deficits, which are not severe enough to produce a DWI lesion, might be suggested as another mechanism.

The other mechanism of DWI-negative ischemic stroke can be attributed to recanalization, which makes the DWI image appear normal $(17,18)$. Spontaneous recanalization could be seen in up to $25 \%$ of cases with ischemic stroke $(19,20)$; however, when it occurs very early it might lead to "aborted stroke". The accompanying pseudo-normalization of the DWI signal might obscure the appearance in initial imaging, which might become conspicuous during follow-up. The spontaneous recanalization phenomenon is related to both clinical improved outcomes and electrophysiologic recovery $(15,21)$. This scenario is equivalent to TIA when it occurs spontaneously, not as a result of recanalization treatments such as thrombectomy.

\section{Study Limitations}

In addition to strong features such as being a systematic review/ pictorial assay with the largest number of patients ever performed, our article also has some limitations. In addition, the use of only the English language for literature search, the limited number of keywords selected, and no request for additional information from the authors are considered minor limitations. Furthermore, as an inevitable nature of systematic reviews, publication bias could not be ruled out due to significant heterogeneity in population characteristics, imaging timing, and parameters including MRI field strength. Finally, because no comparison with patients DWI-positive stroke was made, the specificity of the syndromes described could not be clarified.

\section{Conclusion}

In this analysis, in which we combined our own experience with a literature review, we documented that diffusion-negativity was more frequent than it was thought in acute stroke, it occurred with many different mechanisms and the corresponding clinical syndrome was not specific. Stroke cannot be excluded in many clinical scenarios because "early" diffusion imaging is negative. However, the term "early" is not a simple time interval, but a process that varies individually for a given patient. There is no doubt that further, preferably prospective, studies are needed in this regard. In the current situation, our study carries importance by reporting clear rates for DWI negativity in acute ischemic stroke, revealing this separately for presumed mechanisms, compiling the largest number of patients, describing at least some of the syndromes in sufficient detail.

\section{Ethics}

Ethics Committee Approval: Approval was obtained from Hacettepe University Non-Interventional Clinical Research Ethics Committee for this study (decision number: 2020/16-25, date: 06/10/2020)

Informed Consent: Due to the retrospective nature of the study no informed consent was obtained from patients. Only ethics committee board approval was gathered.

Peer-review: Externally and internally peer-reviewed.

\section{Authorship Contributions}

Surgical and Medical Practices: M.Y.P., E.M.A., R.G., K.K.O., M.A.T., Concept: M.Y.P., E.M.A., R.G., K.K.O., M.A.T., Design: M.Y.P., E.M.A., M.A.T., Data Collection or Processing: M.Y.P., M.A.T., Analysis or Interpretation: M.Y.P., E.M.A., R.G., K.K.O., M.A.T., Literature Search: M.Y.P., M.A.T., Writing: M.Y.P., E.M.A., R.G., K.K.O., M.A.T.

Conflict of Interest: No conflict of interest was declared by the authors.

Financial Disclosure: The authors declared that this study received no financial support.

\section{References}

1. Rosso C, Drier A, Lacroix D, et al. Diffusion-weighted MRI in acute stroke within the first 6 hours: 1.5 or 3.0 Tesla? Neurology 2010;74:1946-1953.

2. Makin SD, Doubal FN, Dennis MS, Wardlaw JM. Clinically confirmed stroke with negative diffusion-weighted imaging magnetic resonance imaging: longitudinal study of clinical outcomes, stroke recurrence, and systematic review. Stroke 2015;46:3142-3148.

3. Watts J, Wood B, Kelly A, Alvaro A. Stroke syndromes associated with DWI-negative MRI include ataxic hemiparesis and isolated internuclear ophthalmoplegia. Neurol Clin Pract 2013;3:186-191.

4. Edlow BL, Hurwitz S, Edlow JA. Diagnosis of DWI-negative acute ischemic stroke: A meta-analysis. Neurology 2017;89:256-262.

5. Hotter B, Kufner A, Malzahn U, et al. Validity of negative high-resolution diffusion-weighted imaging in transient acute cerebrovascular events. Stroke 2013;44:2598-2600.

6. Eastwood JD, Engelter ST, MacFall JF, Delong DM, Provenzale JM. Quantitative assessment of the time course of infarct signal intensity on diffusion-weighted images. AJNR Am J Neuroradiol 2003;24:680-687.

7. Ract I, Ferre JC, Ronziere T, et al. Improving detection of ischemic lesions at 3 Tesla with optimized diffusion-weighted magnetic resonance imaging. J Neuroradiol 2014;41:45-51. 
8. Entwisle T, Perchyonok Y, Fitt G. Thin section magnetic resonance diffusion-weighted imaging in the detection of acute infratentorial stroke. J Med Imaging Radiat Oncol 2016;60:616-623.

9. Aragao Homem C, Fonseca AC, Geraldes R, Pinho e Melo T. Brain magnetic resonance with negative diffusion-weighted imaging: does it preclude acute stroke diagnosis? J Stroke Cerebrovasc Dis 2015;24:e251-e253.

10. Oppenheim C, Stanescu R, Dormont D, et al. False-negative diffusionweighted MR findings in acute ischemic stroke. AJNR Am J Neuroradiol 2000;21:1434-1440.

11. Dijkhuizen RM, Knollema S, van der Worp HB, et al. Dynamics of cerebral tissue injury and perfusion after temporary hypoxia-ischemia in the rat: evidence for region-specific sensitivity and delayed damage. Stroke 1998;29:695-704.

12. Choi JH, Park MG, Choi SY, et al. Acute transient vestibular syndrome: prevalence of stroke and efficacy of bedside evaluation. Stroke 2017;48:556562.

13. Lefkowitz D, LaBenz M, Nudo SR, Steg RE, Bertoni JM. Hyperacute ischemic stroke missed by diffusion-weighted imaging. AJNR Am J Neuroradiol 1999;20:1871-1875.
14. Hossmann KA. Viability thresholds and the penumbra of focal ischemia. Ann Neurol 1994;36:557-565.

15. Wang PY, Barker PB, Wityk RJ, et al. Diffusion-negative stroke: a report of two cases. AJNR Am J Neuroradiol 1999;20:1876-1880.

16. Usnich T, Albach FN, Brunecker P, Fiebach JB, Nolte CH. Incidence of new diffusion-weighted imaging lesions outside the area of initial hypoperfusion within 1 week after acute ischemic stroke. Stroke 2012;43:2654-2658.

17. Cho TH, Hermier M, Alawneh JA, et al. Total mismatch: negative diffusion-weighted imaging but extensive perfusion defect in acute stroke. Stroke 2009; 40:3400-3402.

18. Muir KW, Buchan A, von Kummer R, Rother J, Baron JC. Imaging of acute stroke. Lancet Neurol 2006;5:755-768.

19. Gonzalez RG. Clinical MRI of acute ischemic stroke. J Magn Reson Imaging 2012;36:259-271.

20. Rha JH, Saver JL. The impact of recanalization on ischemic stroke outcome: a meta-analysis. Stroke 2007;38:967-973.

21. Vang C, Dunbabin D, Kilpatrick D. Effects of spontaneous recanalization on functional and electrophysiological recovery in acute ischemic stroke. Stroke 1999;30:2119-2125. 